\title{
Economy of Production and Labor Requirement in Major Field Crops of Kavre, Nepal
}

\author{
Bibek Dhital
}

HASERA Agriculture Research and Training Center, Nepal

\begin{abstract}
Economic analysis is found as the major aspect of measurement of efficiency of a farm. In most cases, this part is lagging in Nepalese farmers. With the objective to find benefit cost ratio of growing different crops, identify profitable crops and estimate labor requirement for cultivation, this case study was performed. The scope of this case study is it helps farmers in selecting the crop comparing the profit and labor available. This study was done as a case study in Kavre district, Nepal. From this research, potato (B: $C=2.44)$ and onion ( $B: C=1.95$ ) were found the most profitable crops and wheat and maize the least. Labor requirement for onion was highest 643 men/ha and wheat was the lowest i.e. $142 \mathrm{men} / \mathrm{ha}$.
\end{abstract}

Keywords - Benefit Cost ratio, Economic analysis, Hill farming, Labor, Nepal, Profit.

\section{INTRODUCTION}

Agriculture is the major source of Nepal's economy contributing about 33\% in GDP (Karki, 2015) and is major source of food, income and employment for $65.7 \%$ of population (Karki, 2015). Those crops which are a part of everyday meal or occupy an important part in socioeconomic life of farmers are major crops. Ecologically Nepal consists of three major geographical division viz. Terai, mid hills and high hills. Terai is considered as the grain basket of the country as it harvests most of the countries staple food where rice followed by maize and wheat are the major cereal crops (NARC, 2013). In mid and higher hills cropping pattern is mainly dominated by maize (Tripathi and Jones2010). In Kavre, in terms of cereals, maize accounts the highest production followed by rice and wheat (MoAD, 2013). Potato is major cash crop followed by onion and mustard is grown as an oil seed crop (MoAD, 2013).Combination of livestock, forest and crop is typical in Nepalese agriculture system (Tripathi and Jones2010). Due to topographical disadvantage traditional methods of agricultural practices and animal power are still major in the hills and high hills but in Terai mechanization is seen (Shrestha, 2012).

The importance of agriculture sector and its overall development is directly linked with the objectives of meeting basic needs of the people (Karki, 2015). Increasing farm production and farmers' income is primarily dependent on farm planning (Karki, 2015).
$65.7 \%$ of population is dependent on agriculture for livelihood and $60 \%$ of these farmers are subsistence farmers because of small land holding (Karki, 2015).Due to higher competition and agri-business challenges (Ghimire, 2008), credit and labor deficiency (Maharjan et al 2013) return to small land holding farmers is decreasing. Economic analysis of farming system will help them and the concerned development facilitators to make proper decisions required for further improvement (Karki, 2015). It helps in determination of successfulness and sustainability of a farm and farming practices.

Economic analysis of agricultural crops includes estimation of cost incurred during cultivation and the monetary output we obtain from our harvest. In mathematical term, profit or loss is expressed as Benefit Cost ratio (B: $\mathrm{C}$ ) which is the ratio of gross return to total cost of cultivation (Adhikari, 2011). In agriculture, crops and cropping practice with $\mathrm{B}$ : $\mathrm{C}$ higher than 1.5 is regarded as economically viable for farmers.

Farmers of Nepal are mostly illiterate and are farming in rural context with very less extent of mechanization (Ghimire, 2008). Majority of farmers of Kavre donot know the economic situation of their cropping pattern and practice. The major objective of this study is to find the benefit cost ratio, unit cost of production of different crops grown in Kavre district. This study also aimsto find the most profitable crop and to estimate the labor requirement for growing different crops. This study will help farmers and developmental organization involved to plan their farming pattern according to the economic status and labor availability, as labor and economics are the two of the major factors responsible for crop production.

\section{METHODOLOGY OF STUDY}

This study was conducted as a case study. This case study involved site selection, data collection, literature review, data analysis etc.

\section{Site Selection:}

Pathlekhet VDC (Ward no 1, 3,4), Pankhalmunicipality (Ward no. 11,13) and Kasikhandamunicipality(Ward no. 6, 3)of Kavre districtwere selected as the site for the study. Pathlekhetis 41KM and Kasikhanda municipality is $51 \mathrm{Km}$ east of Kathmandu in BP highway and Pankhal lies 
20KM from Dhulikhel on Araniko highway. Pathlekhet is at 1100 to 1400 masl, Pankhal is at 700-1100 and Kasikhanda is a bit lower i.e. 950-1200masl. Farmers with average land holdings of about 0.3-0.5 Ha (Survey result) are dominant in the district. Major occupation of most of the people (>80\%) being agriculture, it occupies an important position in social and economic life. Being in hilly area, mechanization is very poor (Kasikhandaand Pankhallittle more mechanized than pathlekhet).In pathlekhet, sill animal are the major draft power. Few mini tillers/power tillers are seen in the fields with road access. For intercultural operations like weeding, irrigation harvesting, threshing manual labor is the only power to depend on. In some family paddle thresher is seen but farmers don't prefer paddle thresher as the quality of straw is low. About $90 \%$ of the fields are rain fed and remaining $10 \%$ is irrigated. Due to low mechanization and transport facility, cost of production seems higher as compared to mechanized part of the country.

\section{Data Collection:}

The method applied for the collection of data was interview with key informants (leader farmers, Agricultural officers)and with with local farmers growing different crops. The data collected was primarily quantitative by using standard open ended questionnaire. Cost was calculated as a function of labor, manure, fertilizer, machinery/tools, food and other inputs. income was estimated by calculating the market value of economic yield i.e. grain and straw in rice and wheat, grain in maize and mustard, bulb in onion and tuber in potato. Pretesting was done with 5 respondents of pathlekhet VDC. A total of 35 respondents were interviewed. Separate data was collected for separate parcel of land (for those farmers having more than one parcel). Respondents were selected at random. Data collection was done in 2015.

\section{RESULT AND DISCUSSION}

Major crops and cropping pattern:

Difference in cropping patter in lowland (Khet) and upland (Bari) is common.In Khet land farmers practice rice based cropping pattern where most of the farmers grow 2 season rice, rainy and spring. Apart from rice, maize, wheat, potato, onion is popular. While in Bari land there is maize based cropping pattern. In Bari wheat, mustard, potato onion and vegetables are grown along with maize. In general, major crops for Kavre district are Rice, Maize, Wheat, Onion, Mustard and Potato.

Table.1: Major crops grown in village as per the \% of farmers involved. (Very small scale i.e. kitchen garden, backyard garden aren't considered).

\begin{tabular}{l|l} 
Crop & $\%$ of farmers involved \\
\hline Rice & $95 \%$ \\
\hline Maize & $100 \%$ \\
\hline Wheat & $60 \%$ \\
\hline Onion & $\mathbf{7 0 \%}$ \\
\hline Mustard & $\mathbf{6 0 \%}$ \\
\hline Potato & $\mathbf{9 8 \%}$
\end{tabular}

(Source: - Survey Research) In terms of number of farmers involved, maize occupies the $1^{\text {st }}$ position. It is so as maize can be grown in both Khet and Bari land. For rice, about 5\% farmers only have Bari land and have no area suitable for rice. In case of wheat, as potato harbors more return per unit area (Table 2) and growing season of wheat and potato overlap in Khet land, more farmers are involved in potato than wheat. Also because of harvesting and threshing difficulty in wheat, farmers tend to grow other crop instead of wheat. Onion requires more labor per unit area (Table 4), so onion is cultivated by fewer farmers. For mustard, because of low productivity and farmers prioritizing for staple crops, only farmers with bigger land holding tend to grow mustard.

Table.2: Cost of production and value of output, Benefit: Cost and variance between respondents of rice, maize, wheat, onion, mustard and potato of Kavre district.

(In case of rice and wheat, both grain and straw are considered)

\begin{tabular}{|c|c|c|c|c|c|c|}
\hline \multirow[t]{2}{*}{ Crop } & \multirow{2}{*}{$\begin{array}{l}\text { Average Cost } \\
\text { per Hectare } \\
\text { (NRs.) }\end{array}$} & \multirow{2}{*}{$\begin{array}{l}\text { Average Income } \\
\text { per Hectare } \\
(\mathrm{NRs})\end{array}$} & \multicolumn{3}{|c|}{ Benefit : Cost (B:C) } & \multirow{2}{*}{$\begin{array}{l}\text { Coefficient } \\
\text { variation } \\
\text { cost })\end{array}$} \\
\hline & & & Min & Max & Average & \\
\hline Rice & 162380.00 & 185746.00 & 1.0493 & 1.723 & 1.1439 & $20.19 \%$ \\
\hline Maize & 114623.20 & 106250.00 & 0.8 & 1.035 & 0.9269 & $21.32 \%$ \\
\hline Wheat & 59268.00 & 72811.42 & 0.92 & 1.554 & 1.228 & $14.54 \%$ \\
\hline Onion & 390613.00 & 762000.00 & 1.02 & 2.22 & 1.9507 & $18.46 \%$ \\
\hline Mustard & 44997.00 & 68294.00 & 1.182 & 1.960 & 1.5177 & $10.61 \%$ \\
\hline Potato & 243846.6 & 562983.2 & 1.49 & 3.29 & 2.44 & $32.20 \%$ \\
\hline
\end{tabular}

(Source: - Survey Research) 
Study shows that, potato and onion are the most profitable crop followed by mustard, rice, wheat and maize. Even though rice, wheat and maize are less profitable, maize followed by rice and wheat are the crops grown by majority of farmers as it is the staple food. In case of rice, transplanting, weeding and harvesting cover the major fraction (50-60\%) of the total cost. Use of transplanters, weeding and harvesting machines might be a way to increase B:C of rice. Similarly, in maize fertilizer covers the major fraction of cost (30-40\%) and Stover of maize doesn't give any return. Use of improved variety can help to enhance $\mathrm{B}$ : $\mathrm{C}$ of maize.

Table.3: Unit cost of production and market value of output of rice, maize wheat, onion, mustard and potato of Kavre district.

(In case of rice and wheat only grains is considered)

\begin{tabular}{l|l|l|l|l}
\multirow{2}{*}{ Crop } & \multicolumn{2}{|l|}{ Unit cost of production Cost/Kg (NRs) } & $\begin{array}{l}\text { Market value of output } \\
\text { Price/Kg (NRs) }\end{array}$ \\
\cline { 2 - 4 } & Min & Max & Average & $35-45$ \\
\hline Rice & 30.94 & 45.94 & 36.84 & $27-32$ \\
\hline Maize & 24.21 & 31.22 & 27.27 & $24-26$ \\
\hline Wheat & 23.87 & 53.63 & 40.61 & $60-130$ \\
\hline Onion & 20.97 & 31.32 & 25.09 & $55-60$ \\
\hline Mustard & 17.62 & 45.07 & 32.38 & $20-40$
\end{tabular}

(Source: - Survey Research)

Table.4: Average labor requirement (men/ha) for cultivation of rice, maize, wheat, onion, mustard and potato of Kavre district and variance between respondents.

\begin{tabular}{l|l|l}
\hline Crop & No. of labor/Ha & Variance between respondents \\
\hline Rice & 360 & $12.59 \%$ \\
\hline Maize & 173 & $12.75 \%$ \\
\hline Wheat & 142 & 26.94 \\
\hline Onion & 643 & $10.37 \%$ \\
\hline Mustard & 256 & $12.27 \%$ \\
\hline Potato & 210 & $11.09 \%$
\end{tabular}

Source: Survey Research

Rice (360 man days/ Ha) after onion (643 man days /Ha) is the most labor requiring crops in mid-hills. Though onion requires high labor, because of its high market value (Table 3 ) and higher return per unit area (Table 2), it is popular among farmers as a cash crop.

\section{DISCUSSION}

This obtained result of benefit cost ratio is supported by different scientists. According to Adhikari2011, Ghemire 2013 andMoAD 2013, BC ratio of rice is 1.15, 1.42 and 1.293 respectively. Timsina, 2011 and MoAD, 2013 found $\mathrm{BC}$ ratio of potato to be 2.9 and 1.79 respectively. Paudel, 2008, Ghemire, 2013 and MoAD, 2013found BC ratio of Maize as 1.03, 1.1 and 1.18 respectively. Mishra, 2010 estimated the maximum BC ratio of Mustard as 2 and Dhakal, 2015 estimated the average $\mathrm{BC}$ ratio of Mustard as 1.43. Ghemire, 2013 and MoAD said wheat can give average benefit cost ratio of 1.38 and 1.275 respectively.Bhandari 2015 reported maximum $\mathrm{BC}$ ratio of onion as 2.48 .

\section{ACKNOWLEDGEMENT}

I would like to offer my sincere thanks to HASERA Agriculture Research Centre, Mr.Govinda Sharma, all the farmers involved in providing the information, and all others who indirectly helped in completion of this study.

\section{REFERENCES}

[1] B Mishra, RN Chaudhary. 2010. Sustainability of productivity in rice-mustard sequential cropping system through integrated nutrient management for Terai condition of Nepal. Agronomy Journal of Nepal, (Agron JN) Vol. 1: 2010.

[2] NB Bhandari. 2015. Ministry of Agriculture Development. Average Production cost and Profit Margin of Pulse, Oilseed, Spice and Commercial Crops. Available at: http://www.doanepal.gov.np/downloadfile/Pulses $\% 2$ Obook_1444370865.pdf 
[3] BP Tripathi, JE Jones. 2010. Biophysical and socioeconomic tools for assessing soil fertility: A case of western hills, Nepal. Agronomy journal of Nepal. V (1). Available at: http://www.nepjol.info/index.php/AJN/article/view/ $\underline{7536}$

[4] KP Timsina, K Kafle, S Sapkota.2011. Economics of potato (Solanumtuberosum L) production in Taplejung district of Nepal. Agronomy Journal of Nepal (Agron JN) Vol. 2: 2011

[5] MoAD. 2013. Statistical Information on Nepalese Agriculture. Available at: http://www.moad.gov.np/uploads/files/YearBook\%2 02013.pdf

[6] NARC. 2013. Annual Report. NARC Publication Serial No. 0006-2013/14. Available at: http://narc.gov.np/publicaton/pdf/book/CPDD\%20A nnual\%20Report 2069-70.pdf

[7] NB Bhandari, D Bhattarai. M Aryal. 2015. COST, PRODUCTION AND PRICE SPREAD OF CEREAL CROPS IN NEPAL : A time series analysis. MoAD. Available at: http://www.doanepal.gov.np/downloadfile/abstract\% 20book\%20setup_1444370508.pdf

[8] P Paude. A Matsuoka. 2008. The System and Profitability of Community-Based Maize Seed Production in Nepal, A Case Study of Chitwan District. Available at: https://www.jstage.jst.go.jp/article/arfe/45/1/45_1_1 67/ pdf

[9] R. Adhikari, 2011. Economics of organic rice production. The journal of agriculture and environment vol:12. Available on: www.nepjol.info/index.php/AEJ/article/download/7 569/6152,

[10] S Ghemire, SM Dhungana, V Krishna. N Teufel and DP Sherchan. 2013. Biophysical and Socioeconomic characterization of cereal production system of central Nepal. CIMMYT Working paper 9. Available at: https://books.google.com.np/books?id=W2HtOnlaB bcC\&pg=PA10\&lpg=PA10\&dq=benefit+cost+ratio +wheat+nepal\&source=bl\&ots=fQ5C-RAOX-

$\underline{\text { sig=A YHwxyaodaxUyLBMJ NiBhe794\&hl=en }}$ \&sa=X\&ved=0ahUKEwjglZObg5bRAhXBP48KHS 6mAEIQ6AEISTAG\# $\mathrm{v}=$ onepage $\& \mathrm{q}=$ benefit $\% 20 \mathrm{cos}$ t\%20ratio\%20wheat $\% 20$ nepal $\& \mathrm{f}=$ false

[11]SC Dhakal, PP Regmi, RB Thapa, D.B KhatriChhetri. 2015. Resource use efficiency of mustard production in Chitwan district of Nepal. Int $\mathrm{J}$ ApplSciBiotechnol, Vol 3(4): 604-608.

[12] Shree Ram Ghimire. 2008. Environmental concern in Nepalese agriculture. The journal of agriculture and environment. Vol (9). Available on: http://ncf.org.np/upload/files/570_en_6shree ram.pd f

[13] Shreematshrestha, 2012. Status of agriculture mechanization in Nepal. Available athttps://www.researchgate.net/publication/2285343 $\underline{87}$

[14] Yogendra Kumar Karki. 2015. Nepal Portfolio Performance Review (NPPR). MoAD Available at: http://mof.gov.np/ieccd/pdf/Agriculture_NPPR2015.pdf 